Org Lett. 2016 April 1; 18(7): 1590-1593. doi:10.1021/acs.orglett.6b00450.

\title{
Palladium-Catalyzed Benzylic Arylation of Pyridylmethyl Silyl Ethers: One-Pot Synthesis of Aryl(pyridyl)methanols
}

\author{
Alexandra R. Rivero ${ }^{\dagger} \neq$, Byeong-Seon Kim ${ }^{\dagger}$, and Patrick J. Walsh ${ }^{\star}, \dagger$ \\ †Roy and Diana Vagelos Laboratories, Penn/Merck Laboratory for High-Throughput \\ Experimentation, Department of Chemistry, University of Pennsylvania, 231 South 34th Street, \\ Philadelphia, Pennsylvania 19104-6323, United States \\ ‡Departamento de Química Orgánica I, Facultad de Ciencias Químicas, Universidad \\ Complutense de Madrid, 28040 Madrid, Spain
}

\begin{abstract}
An efficient palladium-catalyzed direct arylation of pyridylmethyl silyl ethers with aryl bromides is described. A Pd(OAc) 2 /NIXANTPHOS-based catalyst provides aryl(pyridyl)-methyl alcohol derivatives in good to excellent yields (33 examples, $57-100 \%$ yield). This protocol is compatible with different silyl ether protecting groups, affording either the protected or the free alcohols in an effective one-pot process. The scalability of the reaction is demonstrated.
\end{abstract}

\section{Graphical Abstract}

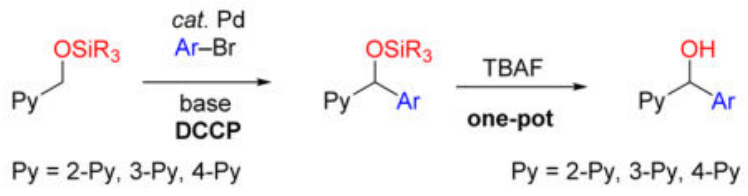

Nitrogen heterocycles are among the most widespread structural components of pharmaceuticals. ${ }^{1}$ Among these, pyridines are frequent subunits of medicinally relevant molecules and materials. ${ }^{1 \mathrm{~g}-\mathrm{n}}$ Specifically, the aryl(pyridyl)-methanol core is commonly found in drug candidates, either as the free alcohol or ether (Figure 1). ${ }^{2}$

Palladium-catalyzed benzylic arylation of picolinyl derivatives has been employed to access heterocyclic building blocks. ${ }^{3}$ Traditionally, such reactions require the presence of directing groups, such as 2-(2-pyridyl)ethanols, ${ }^{3 \mathrm{~b}}$ pyridine $\mathrm{N}$-oxides, ${ }^{3 \mathrm{~d}, 4} \mathrm{~N}$-iminopyridines, ${ }^{3 \mathrm{e}}$ or 2 -(2pyridyl)acetic acids. ${ }^{3 \mathrm{~h}}$ Other methods for the benzylic functionalization of substituted pyridines rely on the addition of activating agents. For instance, a Lewis acid can be added to the reaction mixture to bind the pyridyl nitrogen, preventing its coordination while also

\footnotetext{
*Corresponding Author: ; Email: pwalsh@sas.upenn.edu

Notes

The authors declare no competing financial interest.

* Supporting Information

The Supporting Information is available free of charge on the ACS Publications website at DOI: 10.1021/acs.or-glett.6b00450.

Experimental details and characterization data for all new compounds (PDF)
} 
increasing the acidity of the benzylic hydrogens and facilitating the catalytic process. ${ }^{3 \mathrm{j}, 5}$ Although effective, these methods have limited substrate scope and reduced synthetic efficiency. The coordination of the pyridyl group to palladium and inhibition or deactivation of the catalyst is also problematic. ${ }^{6}$

Given the success of deprotonative cross-coupling processes (DCCP) in the functionalization of a variety of weakly acidic $\mathrm{sp}^{3} \mathrm{C}-\mathrm{H}$ bonds, ${ }^{7}$ we envisioned application of this approach to the functionalization of substituted pyridines. ${ }^{7 \mathrm{q}, \mathrm{u}}$ We recently reported the $\mathrm{Pd}(\mathrm{OAc})_{2} /$ NIXANTPHOS-catalyzed DCCP of pyridylmethyl ethers to generate either arylated secondary ethers (Scheme 1A) or tertiary alcohols via tandem arylation/ [1,2]-Wittig rearrangement (Scheme 1B). ${ }^{7 \mathrm{u}}$ Secondary aryl-(pyridyl)methanols (Figure 1) are also highly desirable but not accessible via the chemistry in Scheme 1A or B.

We hypothesized that pyridylmethyl silyl ethers might undergo reversible deprotonation in the presence of a palladium catalyst and aryl bromides to generate arylated silyl ethers or the corresponding free alcohols (Scheme 1C). Herein, we report the catalytic arylation of pyridylmethyl silyl ethers to afford either the silyl protected or free alcohols, using a Pd(NIXANTPHOS)-based catalyst.

Based on the general utility of the $\mathrm{Pd}(\mathrm{OAc})_{2}$ /NIXANT-PHOS-based catalyst in a range of reactions, ${ }^{7 \mathrm{j}-\mathrm{u}}$ we began by investigating the benzylic $\mathrm{C}-\mathrm{H}$ arylation of 2-pyridylmethyl silyl ether 1a with bromobenzene 2a using $\mathrm{Pd}(\mathrm{OAc})_{2}(1 \mathrm{~mol} \%)$ and NIXANTPHOS (1.5 mol \%, see Table 1 for structure). Several combinations of silyl amide bases $\mathrm{MN}\left(\mathrm{SiMe}_{3}\right)_{2}(\mathrm{M}=\mathrm{Li}$, $\mathrm{Na}, \mathrm{K}$ ) and solvents [toluene, 1,4-dioxane, THF, 2-methyltetrahydrofuran (2-MeTHF), cyclopentyl methyl ether (CPME), and 1,2-dimethoxyethane (DME)] were evaluated to identify suitable reaction conditions (Table 1, entries 1-10).

It was found that $\mathrm{LiN}\left(\mathrm{SiMe}_{3}\right)_{2}$ in DME provided a quantitative yield of the desired coupling (Table 1, entry 6). Unfortunately, attempts to decrease the amount of $\mathrm{LiN}-\left(\mathrm{SiMe}_{3}\right)_{2}$ from 3 equiv to 1.5 equiv resulted in incomplete reaction after $18 \mathrm{~h}$ at $45^{\circ} \mathrm{C}$ (entries 6 and 11). Increasing the temperature from 45 to $85{ }^{\circ} \mathrm{C}$ and using 1.5 equiv of $\mathrm{LiN}\left(\mathrm{SiMe}_{3}\right)_{2}$ led to $98 \%$ yield after $3 \mathrm{~h}$ (entry 12). We were surprised to find that reducing the amount of bromobenzene (2a) to 1.0 equiv still gave $98 \%$ yield (entry 13). Furthermore, only a small drop in the reaction yield (from $98 \%$ to $89 \%$ ) was found when the NIXANTPHOS loading was dropped from 1.5 to $1.0 \mathrm{~mol} \%$ (entries 13 and 14$)$.

With the optimized reaction conditions in hand [pyridyl-methyl silyl ether (1, 1 equiv), aryl

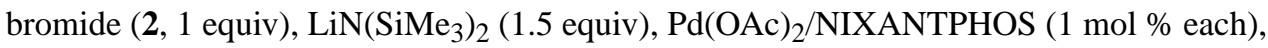
$\operatorname{DME}(0.2 \mathrm{M})$ at $85^{\circ} \mathrm{C}$ ], we explored the scope of aryl bromides in the DCCP (Scheme 2). In general, a variety of aryl bromides (2a-g) led to the formation of aryl(2-pyridyl)methyl silyl ethers 3 with good to high yields (69-88\%). The arylation was compatible with aryl bromides bearing electron-donating substituents 4- $t$-Bu, 4-OMe, 4-NMe 2 (3ac-ae, 84-88\% yield) or electron-withdrawing 4-F and 4-Cl (3af and 3ag in 85\% and 70\% yield, respectively).

The presence of the 2-pyridyl groups in Scheme 2 might lead to the conclusion that chelation is a prerequisite for arylation. Thus, we examined the 4-pyridyl analogues to probe 
this question and expand the method (Scheme 3). The arylation of 4-pyridylmethyl silyl ether $\mathbf{1 b}$ took place at room temperature, suggesting these substrates are more reactive than the 2-pyridyl derivatives. This result is consistent with the greater acidity of 4methylpyridine over 2-methylpyridine. ${ }^{8}$ The reactions of 4-pyridylmethyl silyl ethers provided the desired products with a broad range of aryl bromides. These include electronically neutral (Ph, 2-naphthyl, 4- $t$-Bu,) and electron-rich (4-OMe, 4-NMe 2 ) aryl bromides, which provided products $\mathbf{3 b a}-\mathbf{b e}$ in $83-97 \%$ yield. Aryl bromides with electronwithdrawing groups, such as $4-\mathrm{F}$ and $4-\mathrm{Cl}, 3-\mathrm{CF}_{3}$, formed products $\mathbf{3 b f}-\mathbf{b h}$ in $74-95 \%$ yield. In addition, more challenging substrates, such as sterically hindered 2-bromotoluene and heterocycles (3-bromopyridine, 6-bromoquinoline, 5-bromobenzofuran, and $\mathrm{N}$-methyl-5bromoindole) successfully underwent DCCP at room temperature (3bi-bm, 57-85\%), albeit at $5 \mathrm{~mol} \%$ catalyst loading (Scheme 3). Moreover, the scalability of the method was evaluated by performing the arylation of 4-pyridylmethyl silyl ether $\mathbf{1 b}$ with bromobenzene (2a) on a $4 \mathrm{mmol}$ scale. The desired product (3ba) was obtained in $91 \%$ yield $(1.09 \mathrm{~g}$, Scheme 3).

Next, we assessed different silyl groups. In order to evaluate the impact of silyl group size on the arylation reaction outcome, triisopropylsilyl (TIPS) ether and trimethylsilyl (TMS) ether protecting groups were examined.

Both 2- and 4-pyridine derivatives with TIPS and TMS groups coupled with aryl bromides to provide the desired products in good to excellent yields (57-100\%, Scheme 4). 2-Pyridylcontaining substrates with bulky TIPS groups required 3 equiv of base and $2 \mathrm{~mol} \%$ catalyst loading for complete conversion.

Finally, we explored the feasibility of a one-pot arylation/ desilylation sequence to generate free secondary alcohols. Substrates with different silyl groups were arylated under the standard reaction conditions and then directly treated with 1.5 equiv of TBAF. As shown in Scheme 5, 4-pyridylmethyl silyl ether $\mathbf{1 b}$ and 2-pyridylmethyl silyl ether 1e provided the corresponding alcohols $4 \mathbf{b a}$ and 4 ea respectively, with high yields (94\% and 84\%). The 3pyridylmethyl silyl ether $\mathbf{1 g}$ is more challenging because of the higher $\mathrm{p} K_{\mathrm{a}}$ of the benzylic C-H's. ${ }^{8}$ After some optimization, we found that 3 equiv of $\mathrm{LiN}\left(\mathrm{SiMe}_{3}\right)_{2}, 2$ equiv of 4-tertbutylbromobenzene (2c), and $5 \mathrm{~mol} \%$ catalyst loading in DME at $85{ }^{\circ} \mathrm{C}$ generated arylation product. Workup with 1.5 equiv of TBAF provided the free alcohol $\mathbf{4 g c}$ in $66 \%$ yield.

In summary, a deprotonative cross-coupling process for the direct arylation of pyridylmethyl silyl ethers has been developed. In most cases, this method requires 1 equiv of aryl bromide, 1.5 equiv of base, and many substrates react well at $1 \mathrm{~mol} \%$ catalyst loading. Electrondonating and electron-withdrawing aryl bromides as well as heteroaryl bromides undergo the coupling in good to excellent yields. In addition, the reaction is compatible with different sized silyl-protecting groups. A convenient one-pot cross-coupling/desilylation sequence was demonstrated to directly obtain arylated secondary alcohols. Our method has advantages over the addition of organometallic reagents, such as organolithiums and Grignard reagents, to aldehydes. Many more aryl bromides are commercially available than aryl Grignard reagents. Furthermore, our method circumvents the use of aldehydes, which are often contaminated with oxidation products. We anticipate that this method will be useful in the 
synthesis of aryl pyridylmethyl alcohols for exploration of their structure-activity relationship.

\section{Supplementary Material}

Refer to Web version on PubMed Central for supplementary material.

\section{Acknowledgments}

Financial support for this work was provided by NIH/NIGMS (GM 104349) and the National Science Foundation (CHE-1464744). A.R.R. acknowledges the Spanish MEC for an FPU grant and a Visiting Scientist Fellowship to University of Pennsylvania.

\section{References}

1. (a) Henry GD. Tetrahedron. 2004; 60:6043.(b) Michael JP. Nat Prod Rep. 2005; 22:627. [PubMed: 16193160] (c) Laird T. Org Process Res Dev. 2006; 10:851.(d) Baumann M, Baxendale IR. Beilstein J Org Chem. 2013; 9:2265. [PubMed: 24204439] (e) Taylor RD, MacCoss M, Lawson ADG. J Med Chem. 2014; 57:5845. [PubMed: 24471928] (f) Vitaku E, Smith DT, Njardarson JT. J Med Chem. 2014; 57:10257. [PubMed: 25255204] (g) Jiang Q, Van Plew D, Murtuza S, Zhang X. Tetrahedron Lett. 1996; 37:797.(h) Mazet C, Roseblade S, Köhler V, Pfaltz A. Org Lett. 2006; 8:1879. [PubMed: 16623574] (i) Farina V, Reeves JT, Senanayake CH, Song JJ. Chem Rev. 2006; 106:2734. [PubMed: 16836298] (j) Rennison D, Bova S, Cavalli M, Ricchelli F, Zulian A, Hopkins B, Brimble MA. Bioorg Med Chem. 2007; 15:2963. [PubMed: 17321141] (k) Maywald M, Pfaltz A. Synthesis. 2009; 2009:3654.(1) Catalysis in Asymmetric Synthesis. Wiley-VCH; Chichester, U.K: 2009. (m) Joule, JA.; Mills, K. Heterocyclic Chemistry. 5. John Wiley \& Sons; Chichester, U.K: 2010. (n) Pozharskii, AF.; Soldatenkov, AT.; Katritzky, AR. Heterocycles in Life and Society: An Introduction to Heterocyclic Chemistry, Biochemistry and Applications. 2. John Wiley \& Sons; Chichester, U.K: 2011.

2. (a) Hite G, Barouh V, Dall H, Patel D. J Med Chem. 1971; 14:834. [PubMed: 4400865] (b) De Martino G, La Regina G, Di Pasquali A, Ragno R, Bergamini A, Ciaprini C, Sinistro A, Maga G, Crespan E, Artico M, Silvestri R. J Med Chem. 2005; 48:4378. [PubMed: 15974590] (c) Davies DR, Mamat B, Magnusson OT, Christensen J, Haraldsson MH, Mishra R, Pease B, Hansen E, Singh J, Zembower D, Kim H, Kiselyov AS, Burgin AB, Gurney ME, Stewart LJ. J Med Chem. 2009; 52:4694. [PubMed: 19618939] (d) Lyseng-Williamson KA. Drugs. 2010; 70:1579. [PubMed: 20687621] (e) Yin L, Hu Q, Hartmann RW. J Med Chem. 2013; 56:460. [PubMed: 23281812]

3. (a) Niwa T, Yorimitsu H, Oshima K. Org Lett. 2007; 9:2373. [PubMed: 17497870] (b) Niwa T, Yorimitsu H, Oshima K. Angew Chem, Int Ed. 2007; 46:2643.(c) Hlavinka ML, Hagadorn JR. Organometallics. 2007; 26:4105.(d) Campeau LC, Schipper DJ, Fagnou K. J Am Chem Soc. 2008; 130:3266. [PubMed: 18293986] (e) Mousseau JJ, Larivée A, Charette AB. Org Lett. 2008; 10:1641. [PubMed: 18358041] (f) Schipper DJ, Campeau LC, Fagnou K. Tetrahedron. 2009; 65:3155.(g) Burton PM, Morris JA. Org Lett. 2010; 12:5359. [PubMed: 21043493] (h) Shang R, Yang ZW, Wang Y, Zhang SL, Liu L. J Am Chem Soc. 2010; 132:14391. [PubMed: 20873805] (i) Song G, Su Y, Gong X, Han K, Li X. Org Lett. 2011; 13:1968. [PubMed: 21405051] (j) Duez S, Steib AK, Manolikakes SM, Knochel P. Angew Chem, Int Ed. 2011; 50:7686.(k) Zhao D, Zhu MX, Wang Y, Shen Q, Li JX. Org Biomol Chem. 2013; 11:6246. [PubMed: 23959586]

4. (a) Mai W, Yuan J, Li Z, Yang L, Xiao Y, Mao P, Qu L. Synlett. 2012; 23:938.(b) Kianmehr E, Faghih N, Khan KM. Org Lett. 2015; 17:414. [PubMed: 25607468]

5. (a) Trost BM, Thaisrivongs DA. J Am Chem Soc. 2008; 130:14092. [PubMed: 18826305] (b) Trost BM, Thaisrivongs DA. J Am Chem Soc. 2009; 131:12056. [PubMed: 19645450]

6. (a) Onishi M, Hiraki K, Maeda K, Itoh T. J Organomet Chem. 1980; 188:245.(b) Isobe K, Nakamura Y, Kawaguchi S. Bull Chem Soc Jpn. 1989; 62:1802.(c) Qian B, Guo S, Shao J, Zhu Q, Yang L, Xia C, Huang H. J Am Chem Soc. 2010; 132:3650. [PubMed: 20196596]

7. (a) McGrew GI, Temaismithi J, Carroll PJ, Walsh PJ. Angew Chem, Int Ed. 2010; 49:5541.(b) McGrew GI, Stanciu C, Zhang J, Carroll PJ, Dreher SD, Walsh PJ. Angew Chem. 2012; 124:11678. 
(c) Zheng B, Jia T, Walsh PJ. Org Lett. 2013; 15:1690. [PubMed: 23517309] (d) Jia T, Bellomo A, El Baina K, Dreher SD, Walsh PJ. J Am Chem Soc. 2013; 135:3740. [PubMed: 23419158] (e) Montel S, Jia T, Walsh PJ. Org Lett. 2014; 16:130. [PubMed: 24295336] (f) Zheng B, Jia TZ, Walsh PJ. Org Lett. 2013; 15:4190. [PubMed: 23909856] (g) Montel S, Raffier L, He Y, Walsh PJ. Org Lett. 2014; 16:1446. [PubMed: 24520897] (h) Hussain N, Frensch G, Zhang J, Walsh PJ. Angew Chem, Int Ed. 2014; 53:3693.(i) Zheng B, Jia T, Walsh PJ. Adv Synth Catal. 2014; 356:165.

[PubMed: 24765060] (j) Zhang J, Bellomo A, Creamer AD, Dreher SD, Walsh PJ. J Am Chem Soc. 2012; 134:13765. [PubMed: 22816972] (k) Frensch G, Hussain N, Marques FA, Walsh PJ. Adv Synth Catal. 2014; 356:2517. [PubMed: 25685127] (1) Gao F, Kim BS, Walsh PJ. Chem Commun. 2014; 50:10661.(m) Li M, Berritt S, Walsh PJ. Org Lett. 2014; 16:4312. [PubMed: 25093713] (n) Li M, Yücel B, Adrio J, Bellomo A, Walsh PJ. Chem Sci. 2014; 5:2383. [PubMed: 25396041] (o) Zhang J, Bellomo A, Trongsiriwat N, Jia T, Carroll PJ, Dreher SD, Tudge MT, Yin H, Robinson JR, Schelter EJ, Walsh PJ. J Am Chem Soc. 2014; 136:6276. [PubMed: 24745758] (p) Yuücel B, Walsh PJ. Adv Synth Catal. 2014; 356:3659. [PubMed: 26185491] (q) Kim BS, Jiménez J, Gao F, Walsh PJ. Org Lett. 2015; 17:5788. [PubMed: 26576005] (r) Mao J, Eberle K, Zhang J, Rodríguez-Escrich C, Xi Z, Pericàs MA, Walsh PJ. Tetrahedron Lett. 2015; 56:3604. [PubMed: 26034337] (s) Sha SC, Zhang J, Walsh PJ. Org Lett. 2015; 17:410. [PubMed: 25582024] (t) Cao X, Sha SC, Li M, Kim BS, Morgan C, Huang R, Yang X, Walsh PJ. Chem Sci. 2016; 7:611. [PubMed: 27213035] (u) Gao F, Kim BS, Walsh PJ. Chem Sci. 2016; 7:976. [PubMed: 27014434] (v) Hussain N, Kim BS, Walsh PJ. Chem - Eur J. 2015; 21:11010. [PubMed: 26129922]

8. Fraser RR, Mansour TS, Savard S. J Org Chem. 1985; 50:3232. 
<smiles>O=C(O)CCCN1CCC(OC(c2ccc(Cl)cc2)c2ccccn2)CC1</smiles>

Antihistamine agent<smiles>Cc1ncc([N+](=O)[O-])n1CCOC(c1ccccc1)c1cccnc1</smiles>

HIV-1 NNRT Inhibitor<smiles>CN(C)CCOC(c1ccc(Cl)cc1)c1ccccn1</smiles>
anticholinergic agent<smiles>OC(c1ccncc1)c1ccc(OCCN2CCCC2)cc1</smiles>

Figure 1.

Biologically active compounds containing aryl(pyridyl)-methanol subunits. 
A.

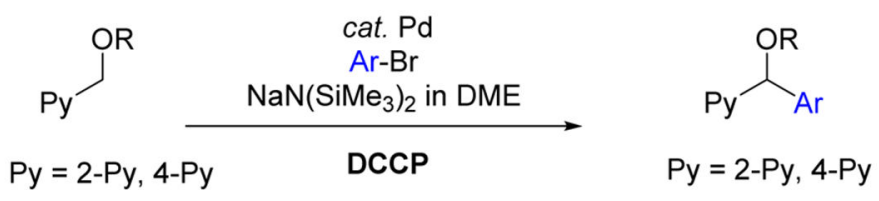

B.

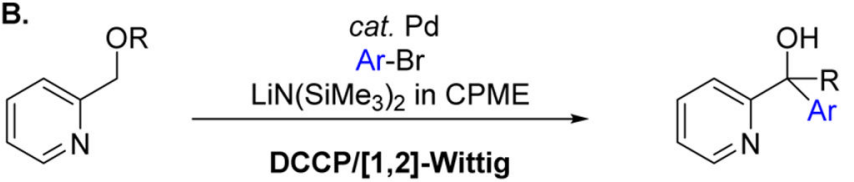

C. This work

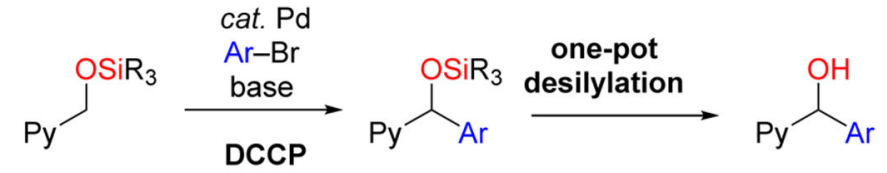

Py = 2-Py, 3-Py, 4-Py Py = 2-Py, 3-Py, 4-Py

Scheme 1.

Pd-Catalyzed Benzylic C-H Arylation of Pyridylmethyl Ethers 


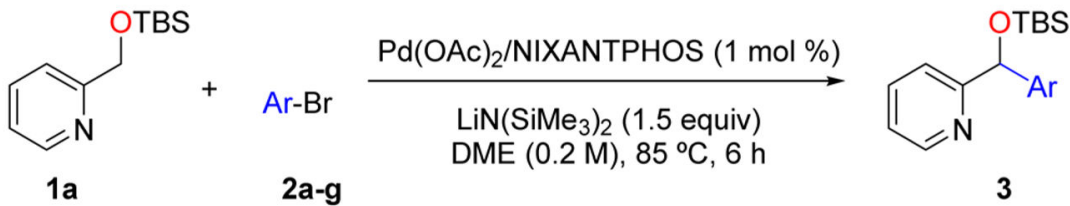

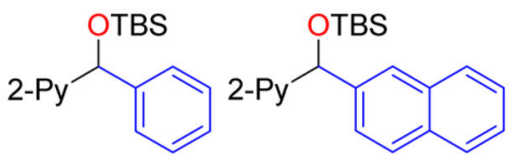

3aa, $77 \%$

3ab, $69 \%$<smiles>[R5]C([18OH])c1ccc(Br)cc1</smiles>

3ac, $84 \%$<smiles>COc1ccc(C([18OH])C([15NH])[Pb])cc1</smiles>

3ad, $88 \%$<smiles>CCCCC([18OH])C([18OH])c1ccc(N(C)C)cc1</smiles>

3ae, $88 \%{ }^{b}$<smiles>[R5]C([18OH])c1ccc(F)cc1</smiles>

3af, $85 \%$<smiles>[R5]C([18OH])c1ccc(Cl)cc1</smiles>

3ag, 70\%

\section{Scheme 2.}

Scope of Aryl Bromides 2 in Benzylic C-H Arylation of 2-Pyridylmethyl Silyl Ether 1a ${ }^{a}$ ${ }^{a}$ Isolated yields with reactions conducted on a $0.2 \mathrm{mmol}$ scale using $\mathbf{1 a}$ (1 equiv), $\mathrm{Ar}-\mathrm{Br}$ (1 equiv), and $\operatorname{LiN}\left(\mathrm{SiMe}_{3}\right)_{2}\left(1.5\right.$ equiv) in $\operatorname{DME}(0.2 \mathrm{M})$ at $85^{\circ} \mathrm{C}$ for $6 \mathrm{~h} .{ }^{b} 4 \mathrm{~h}$. 


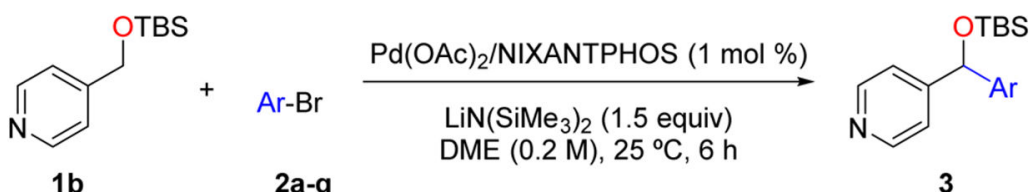<smiles>COc1ccc(C([18OH])[18OH])cc1</smiles>

3ba, $83 \%$

3bb, $76 \%$

3bc, $95 \%$

3bd, $97 \%$

(4 mmol, 91\%)

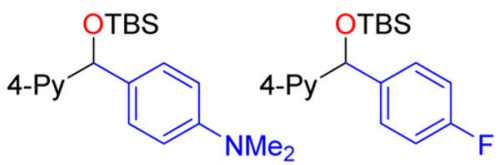

3be, $95 \%^{b}$

3bf, $95 \%$<smiles>[13CH3]C([18OH])c1ccc(Cl)cc1</smiles>

3bg, $74 \%$

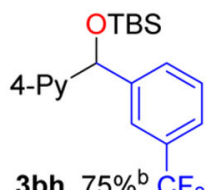

3bh, $75 \%{ }^{\mathrm{b}} \mathrm{CF}_{3}$<smiles>Cc1ccccc1C([Se])O[Se-]</smiles>

$3 \mathrm{bi}, 65 \%^{\mathrm{c}}$<smiles></smiles>

3bj $78 \%$ c,d

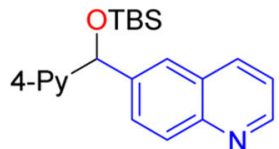

3bk $57 \%$ c,d<smiles></smiles>

3bl $81 \%$ c,d

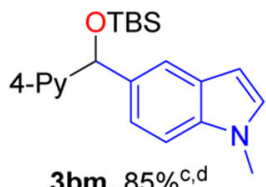

Scheme 3.

Scope of Aryl Bromides 2 in Benzylic C-H Arylation of 4-Pyridylmethyl Silyl Ether $1 b^{a}$ ${ }^{a}$ Isolated yields with reactions conducted on a 0.2 mmol scale using $\mathbf{1 b}$ ( 1 equiv), $\mathrm{Ar}-\mathrm{Br}$ (1 equiv), and $\mathrm{LiN}\left(\mathrm{SiMe}_{3}\right)_{2}$ (1.5 equiv) in $\mathrm{DME}(0.2 \mathrm{M})$ at $25^{\circ} \mathrm{C}$ for $6 \mathrm{~h} .{ }^{b} 24 \mathrm{~h} .{ }^{c} \mathrm{LiN}\left(\mathrm{SiMe}_{3}\right)_{2}$ (3 equiv). ${ }^{d} 5 \mathrm{~mol} \% \mathrm{Pd}(\mathrm{OAc})_{2}$ and $5 \mathrm{~mol} \%$ of NIXANTPHOS. 


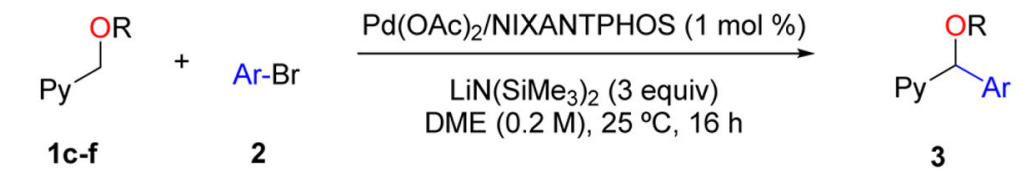<smiles>[AsH3]OC([Pb])c1ccccc1</smiles>

$3 \mathrm{ca}, 57 \%$ b,c

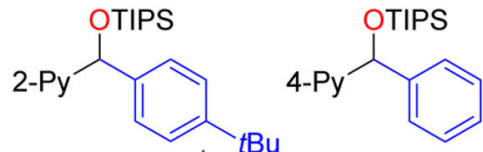

3da, 100\%<smiles>CC(C)(C)c1ccc(C([18OH])C([18OH])[18OH])cc1</smiles>

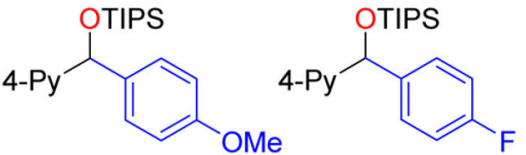

3dd, $94 \%$

3df, $99 \%$<smiles>COC(P)c1ccc(C(C)(C)C)cc1</smiles><smiles>COC(=O)C(OC)c1ccccc1</smiles>

3fa, $94 \%{ }^{\mathrm{C}}$

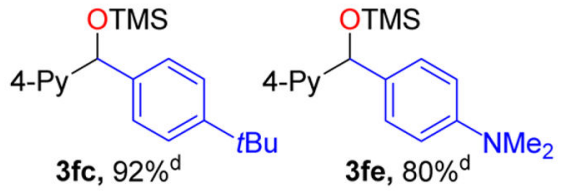

\section{Scheme 4.}

Scope of Arylation of Pyridylmethyl Silyl Ethers ${ }^{a}$

a Isolated yields with reactions conducted on a $0.2 \mathrm{mmol}$ scale using 1 (1 equiv), $\mathrm{Ar}-\mathrm{Br}$ (1 equiv), and $\mathrm{LiN}\left(\mathrm{SiMe}_{3}\right)_{2}\left(3\right.$ equiv) in $\operatorname{DME}(0.2 \mathrm{M})$ at $25^{\circ} \mathrm{C}$ for $16 \mathrm{~h} .{ }^{b} \mathrm{Conducted}$ at $85^{\circ} \mathrm{C} .{ }^{2} \mathrm{~mol} \%$ of $\mathrm{Pd}(\mathrm{OAc})_{2}$ and $2 \mathrm{~mol} \%$ of NIXANTPHOS at $85^{\circ} \mathrm{C} .{ }^{d} \mathrm{LiN}\left(\mathrm{SiMe}_{3}\right)_{2}(1.5$ equiv) for $1.5 \mathrm{~h}$. 


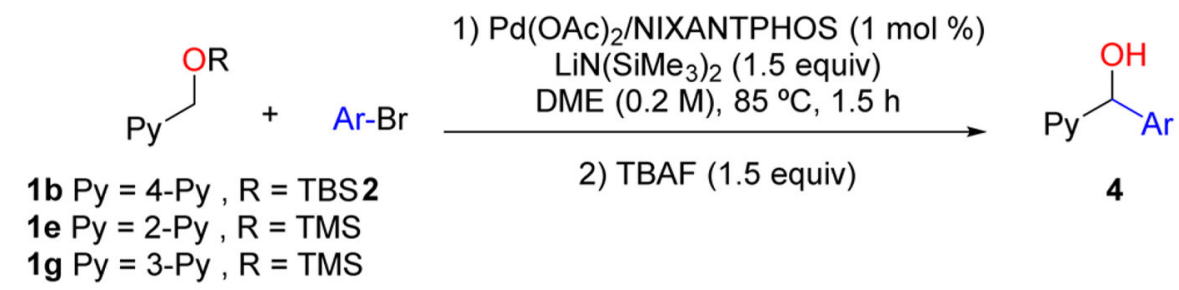<smiles>OC(Br)c1ccccc1</smiles>

$4 \mathrm{ba}, 94 \%^{\mathrm{b}}$<smiles>[R6]C(O)c1ccccc1</smiles>

4ea, $84 \%$<smiles>CC(C)Cc1ccc(C(O)P)cc1</smiles>

$4 \mathrm{gc}, 66 \%^{\mathrm{c}}$

\section{Scheme 5.}

One-Pot Arylation/Deprotection of Pyridylmethyl Silyl Ethers ${ }^{a}$

aIsolateds yields with reactions conducted on a $0.2 \mathrm{mmol}$ scale using 1 (1 equiv), $\mathrm{Ar}-\mathrm{Br}$ (1 equiv), and $\operatorname{LiN}\left(\mathrm{SiMe}_{3}\right)_{2}\left(1.5\right.$ equiv) in $\operatorname{DME}(0.2 \mathrm{M})$ at $85^{\circ} \mathrm{C}$ for $1.5 \mathrm{~h} .{ }^{b} \mathrm{Conducted}$ at $25^{\circ} \mathrm{C} .{ }^{c} \mathrm{Ar}-\mathrm{Br}$ ( 2 equiv), $\mathrm{LiN}\left(\mathrm{SiMe}_{3}\right)_{2}$ ( 3 equiv), $5 \mathrm{~mol} \%$ of $\mathrm{Pd}(\mathrm{OAc})_{2}$, and $5 \mathrm{~mol} \%$ of NIXANTPHOS for $24 \mathrm{~h}$. 
